\title{
"Compre essa ideia, consuma esse produto", ou como a publicidade nos enreda em sua teia
}

\author{
"Take this product, back this idea", said the spider to the fly \\ PATRICIA CeCILIA BURROWES \\ Doutora e Mestre em Comunicação e Cultura pela Universidade Federal do Rio de Janeiro (ECO/UFRJ). Atualmente é professora adjunta \\ da Universidade Federal do Rio de Janeiro. \\ <patricia.burrowes@eco.ufri.br>
}

\section{RESUMO}

Este artigo investiga as estratégias empregadas, ontem e hoje, pela publicidade, para tentar seduzir seu público, produzir-lhe uma impressão duradoura e levá-lo a preferir uma marca, em detrimento de outras. Analisamos duas campanhas: uma da década de 1960, considerada marco da chamada "revolução criativa", e uma vencedora do Festival de Criatividade de Cannes de 2013. Observamos que o recurso à criatividade na publicidade assinala, no primeiro momento, uma mudança do capitalismo, da produção industrial de bens para a de consumo. Hoje vivemos uma "nova revolução criativa" no âmbito da comunicação de marketing. Usam-se técnicas de narrativa para conquistar o engajamento do público, visto como possível interlocutor. Corresponde à mutação do capitalismo,

\begin{abstract}
This paper investigates the strategies employed by advertising, yesterday and today, to try to entice its audience, produce a lasting impression and get it to prefer one brand over others. Two campaigns are analyzed: one considered a landmark of 1960s "creative revolution", and the other a winner of the 2013 Cannes Lions International Festival of Creativity. We note that, at first, the use of creativity in advertising marks a change of capitalism, from industrial production of goods to that of consumption. Today we experience a "new creative revolution" in marketing communications. Storytelling techniques are employed to engage the public, which is seen as an interlocutor. This corresponds to a mutation of capitalism into a "cognitive" kind. We take a
\end{abstract}


para uma modalidade chamada "cognitiva". Apresento uma visão crítica, questionando tal noção de criatividade, e se a publicidade funcionaria como um mecanismo de controle biopolítico.

Palavras-chave: Criatividade. Publicidade. Biopolítica. critical view, questioning such notion of creativity, and asking whether advertising might act as a mechanism of biopolitical control.

Keywords: Creativity. Advertising. Biopolitics.

\section{Revolução criativa?}

Think small, exortava, em 1959, um anúncio de revista para um automóvel da

1 Volkswagen que, dez anos mais tarde, viria a se transformar no popular fusquinha Herbie em The love bug e outros cinco títulos da Disney. No final da década de 1950, entretanto, era um verdadeiro desafio vender para o público americano, nos Estados Unidos, um pequeno carro "do povo", como o nome indica, e concebido na Alemanha nazista. Na contramão da cultura publicitária de sua época, que exaltava o sonho americano na forma da próspera família, com sua casa no subúrbio, seu automóvel rabo-de-peixe e seu consumo ostensivo, a agência Doyle Dane Bernbach, ou simplesmente DDB, propôs para a campanha de lançamento do fusca esse apelo voltado para o bom-senso, a praticidade e, sobretudo, a economia (O Portal da história, s/d).

Celebrada, em março de 1999, pela revista especializada Ad Age como a primeira de uma lista das cem melhores campanhas publicitárias do século XX, a campanha Think small marcou um momento de mudança no cenário da publicidade. Em contraste com a prática dominante em sua época, encampada por Rosser Reeves, de reiterar uma única promessa central de venda (unique selling proposition) em todas as peças publicitárias de um produto ou serviço, de modo a forçar sua memorização e induzir o público 
à compra, o proprietário e líder da DDB, Bernbach, defendia em sua agência uma nova abordagem. Para ele a ênfase devia recair justamente na comunicação: na forma da persuasão. Tratava-se de pensar, selecionar e trabalhar cuidadosamente ideias, palavras, imagens para tornar as afirmações sobre o produto ou marca anunciados mais atrativos e envolventes para o público (Figueiredo, 2007; Hallock, s/d; Pope, 2003).

Nas palavras de Bernbach: "It is one thing to have a selling proposition and quite another to sell it"1. O propósito, segundo Bernbach, era "tocar", "comover" o público. Devemos observar que ele não sugere o abandono de toda promessa básica. Mas defini-la seria apenas o começo do processo. Uma persuasão mais efetiva exigiria tornar a promessa inesperada e fascinante aos olhos das pessoas a que se dirige. Tarefa essa a ser cumprida pela agência de publicidade, mais especificamente pelo departamento de criação, por meio do trabalho da dupla de criação - redator/a e diretor/a de arte - formato de equipe, aliás, inventado por ele. Bernbach, não negava a relevância do "o que dizer", simplesmente afirmava a potência do "como dizer". E rearfirmava o papel comercial dessa verve: "Properly practiced creativity must result in greater sales more economically achieved. Properly practiced creativity can lift your claims out of the swamp of sameness and make them accepted, believed, persuasive, urgent" 2 (DDB, s/d). A essa nova abordagem se deu o nome de revolução criativa, pela preocupação estética que a caracterizava e por sua aproximação com a linguagem da arte. Outro publicitário de renome, David Ogilvy, na década de 1960, se indispunha com o emprego das palavras "criativo" e "criatividade" para designar o trabalho publicitário. E pergunta: "Como conseguíamos nos arranjar a vinte anos, antes que a criatividade entrasse para o vocabulário da publicidade?" (Ogilvy, 2003 [1963], p. 107).

Podemos indagar por que a palavra "criatividade" passa a povoar o ambiente das agências justamente nessa época. Talvez não se trate de um fenômeno localizado, mas de uma mudança discursiva mais ampla. Proponho essa reflexão a partir do trabalho 
de Kastrup (2007 [1999]) a respeito da psicologia da invenção, que ela aponta como uma lacuna, até então, nos estudos da cognição. Segundo a autora, o fenômeno da "criatividade" teria sido alvo de investigação da psicologia, aparecendo em publicações da área "a partir da década de 1950, vindo a ocupar um espaço considerável nos anos 60 e 70, sobretudo nos Estados Unidos", (Kastrup, 2007, p. 17) Tais estudos, explica Kastrup, provenientes da psicologia técnica ou psicométrica, procuravam desenvolver modos de testar e medir a criatividade individual, bem como elaborar técnicas para estimulá-la e treiná-la. A autora aponta um significativo deslocamento a partir desses estudos: a produção criativa passava a ser vista como uma capacidade humana inata, um dos fatores da inteligência, de que todos, portanto, seriam capazes, e não mais considerada, como na primeira metade do século XX, efeito do "gênio". Ela critica, entretanto, o modo como a questão da criatividade é colocada, qual seja, como instrumento de solução de problemas previamente definidos. "São as exigências da sociedade americana que movem tais trabalhos. Para a corrida espacial, para a indústria e a propaganda, cumpre selecionar indivíduos criativos." (Kastrup, 2007, p. 18). O ponto que nos interessa especialmente é a distinção que a autora propõe, a partir de Bergson, entre as noções de "invenção" e "criatividade". Pensar a criatividade como um instrumento "a serviço da solução de problemas" (Kastrup, 2007, p. 19) implica restringir o seu teor de criação, uma vez que a força fundamental desta estaria na invenção dos problemas, - muitas vezes em ruptura com pressupostos e interesses de dada sociedade.

Na publicidade, o recurso crescente a uma criatividade aplicada, que se desenvolve a partir da década de 1960, vem justamente tentar resolver o problema da superprodução, assinalando uma mudança do capitalismo, que transfere seu foco da produção industrial de bens para a produção industrial de consumo, o que exige uma produção industrial de sentido. 
Segundo Hobsbawn (1995), a expansão da sociedade industrial ocorrida após a Segunda Guerra Mundial produziu, pelo menos nos países capitalistas ditos do primeiro mundo, uma prosperidade sem precedentes. O autor lembra-nos que as décadas de 1950 a 1970, não à toa, mereceram o título de Era de Ouro. "A produção mundial de manufaturas quadruplicou entre o início da década de 1950 e o início da década de 1970, e o que é ainda mais impressionante, o comércio mundial de produtos manufaturados aumentou dez vezes" (Hobsbawn, 1995, p. 257).

Nos Estados Unidos, alçado ao posto de modelo mundial de desenvolvimento, a expansão econômica já se fazia sentir durante a Guerra, de modo que o crescimento nos vinte prósperos anos que se seguiram era visto e vivido como continuidade de uma tendência.

Bens e serviços antes restritos a minorias eram agora produzidos para um mercado de massa, como no setor de viagens a praias ensolaradas [...] O que antes era luxo tornou-se padrão de conforto desejado, pelo menos nos países ricos: a geladeira, a lavadora de roupas automática, o telefone."

(Hobsbawn, 1995, p. 259)

Precisamos ainda considerar, como aponta o historiador, o inaudito avanço tecnológico do período entre guerras e pós-guerra, que enchia o mundo de materiais e produtos novos, transformando completamente o modo de vida, agora predominantemente urbano: plásticos, transístores, circuitos integrados, eletrodomésticos, LP, fita cassete, rádio portátil, televisão... "A revolução tecnológica 
entrou na consciência do consumidor em tal medida que a novidade se tornou o principal recurso de venda para tudo, desde os detergentes sintéticos [...] até os computadores laptop. A crença era de que o novo equivalia não só a melhor, mas a absolutamente revolucionado" (Hobsbawn, 1995, p. 261).

Em que pese o valor da novidade da sociedade industrial, o fato é que por volta dos anos 1960 a produção em massa despejava no mercado cada vez mais artefatos cada vez mais similares. E tais produtos já não se vendiam pela sua simples existência. Precisavam se diferenciar de alguma maneira uns dos outros, afirmar sua exclusividade, qualidade, novidade, superioridade. A revolução criativa procurava fazer exatamente isso, por meio da comunicação. O deslocamento, porém, ia além da tentativa de seduzir pela forma das mensagens: a promessa de venda, embora afirmasse ainda características presentes no produto, as associava a valores de uso subjetivos. Notamos essa mudança na própria campanha Think small, que, se oferecia economia, se baseava na proposta de um estilo de vida inconspícuo, em que tal economia era apresentada antes como uma opção pessoal, do que como uma necessidade. Mas a ênfase no estilo de vida pode ser mais claramente percebida em outra campanha, anterior mesmo ao marco da Volkswagen: a dos famigerados anúncios do homem de Malboro, cuja série se inicia nos EUA em 1954 e só termina em 1999. Idealizada na década de 1950, pela agência Leo Burnet, a campanha tinha como objetivo promover o cigarro com filtro, percebido então pelo público como produto feminino. As imagens do cowboy solitário na imensidão da natureza incorporavam um ideal de masculinidade associado a valores como independência, coragem e liberdade. "Venha para onde está o sabor. Venha para a terra de Malboro", convidava o texto. O público visado era jovem recémsaído da adolescência, fumante em início de carreira, para quem era fundamental afirmar sua independência. Em 1972, Malboro, havia alcançado o posto de líder mundial no mercado de tabaco (Evans e Pow, 2014; Novac, 2011). Pode-se entender como, no 
contexto do mundo pós-guerra, numa situação poder global tensionado entre dois blocos, em que duas visões da economia - Capitalista, defensora do livre mercado e da concorrência, e Comunista, planificada pelo Estado - viviam um confronto, numa disputa de influência e força sobre o mundo, a difusão de estilos de vida funcionasse como mecanismo de controle. No Brasil, a "revolução criativa" chegou com força a partir de meados da década de 1960, coincidindo com o fechamento político, o desmonte das instituições da democracia e o agravamento da repressão (Carrascoza, 1999, p.104-105), num momento em que o governo favorecia investimentos em infraestrutura de telecomunicações, de modo a ampliar a penetração da TV, com o duplo objetivo de promover a integração nacional e incentivar a interiorização do mercado de consumo.

\section{Acertar no alvo}

O mercado: isso que, conforme Foucault (2008) se torna o centro das atenções da economia política, e lugar de formação da verdade, a partir do séc. XVIII. Em seu curso do ano de 1978/1979 no Collège de France, publicado no Brasil sob o título "Nascimento da Biopolítica", Foucault argumenta que o mercado era desde os séculos XVI e XVII, e mesmo antes, ainda na Idade Média, lugar privilegiado de regulamentação pelas práticas de governo. Mas, se até o século XVII, tal regulamentação visava evitar fraudes e tinha como critério uma certa noção de justa distribuição dos produtos, em meados do século XVIII passa a ser algo que "obedecia e devia obedecer mecanismos naturais", que levavam à formação do preço natural, bom, normal; um equilíbrio que ocorreria espontaneamente, que não se deveria, portanto, "desnaturar". É nesse sentido que o mercado se torna lugar e mecanismo de formação da verdade; a verdade que o mercado afirma é a da sua natureza, tão necessária quanto todas as verdades das leis naturais (Foucault, 2008, p. 44-45). 
Foucault se detém sobre a economia política porque vê aí a condição de surgimento da Biopolítica. Porque no cerne do mercado, continua Foucault, a naturalidade em questão é a dos indivíduos "na medida em que eles próprios estão ligados a essa naturalidade econômica, em sua quantidade, em sua longevidade, sua saúde, sua maneira de se comportar se encontram em relações complexas e entrelaçadas com esses processos econômicos" (Foucault, 2008, p. 30).

Hoje, já vemos o mercado objeto não apenas das práticas governamentais, mas também das práticas empresariais. Os objetivos do marketing podem ser resumidos a uma batalha pelo mercado: seja para ampliá-lo, abrir novos nichos, consolidar ou defender a parcela que se domina, ou subtrair participação à concorrência. Para apreender a importância da mercadologia seria preciso evocar a afirmação de base da teoria do consumidor: "a demanda se fundamenta no comportamento dos consumidores" (Gremaud e outros, 2003, p. 110). Portanto, influenciar, direcionar, promover e ativar comportamentos favoráveis ao que se deseja vender é um modo de interferir no mercado - e é a função da comunicação de marketing. Modificar a percepção de valor que se tem de uma marca ou produto, estimular a percepção de importância de certos produtos ou de suas características, influenciar a escolha do consumidor são tentativas se utilizar das "leis do mercado" em seu próprio favor. Vemos até que ponto e de que forma essa tentativa de controle pode ser um lugar de exercício de poder.

A identificação do público alvo é um dos procedimentos-chave da elaboração de um plano de marketing. Essa delimitação de consumidores potenciais não só ordena a comunicação, sua abordagem, sua linguagem, os meios que serão empregados para o contato, mas está presente muito antes, já na concepção dos produtos, influenciando desde a sua produção até a sua distribuição. Para identificar tal grupo, a empresa (ou organização) recolhe e analisa dados demográficos, tais como faixa etária, gênero, 
estado civil, grau de instrução, profissão, renda, local de moradia, e informações sobre modos de vida, perfis psicológicos, hábitos e preferências de consumo. Então ela seleciona e ordena as variáveis relevantes no que tange aquilo que tem a oferecer no mercado, seja um produto, um serviço, uma marca ou uma ideia. Em torno dessas variáveis compartilhadas - já agora tratadas como constantes - se condensa o público alvo: necessariamente uma abstração. O marketing detecta "necessidades" no público (atual e potencial) e, para atendê-las, cria produtos e, principalmente, promessas.

A publicidade do produto, serviço ou marca é planejada e direcionada para esse perfil de consumidor construído, tentando por meio de apelos emocionais e/ou racionais expressos em forma de texto, imagem, som etc. atingir o lugar dos supostos desejos não realizados, quiçá irrealizáveis; nas peças de comunicação de marketing, as marcas, produtos, serviços aparecem associados a uma projeção daquilo que o público alvo (poderíamos chamar de leitor implícito) seria, pensaria, sonharia, desejaria. E o mais curioso é que, a julgar não só pelos altos investimentos, mas também pelos resultados obtidos em termos de retorno de vendas e imagem, o estratagema funciona. É evidente que há uma atividade na escolha de consumo: as pessoas não são coagidas, nem vítimas de logro. Iludidas talvez, mas não no sentido de enganadas, e sim no de - in ludere - jogando. Consumir é o nosso jogo. A questão que tem nos interessado é se e como tal produção/distribuição de identidades faz mais do que circunscrever grupos, contribuindo para sua produção, interferindo na sua sociabilidade e na sua subjetividade; funcionando talvez como mecanismo de controle.

Em artigo anterior (Burrowes, 2007) abordei a constituição e o funcionamento de um "agenciamento coletivo do consumo", do qual o marketing seria um operador privilegiado, com suas enunciações. Isso porque conectar corpos e discursos é a base da comunicação mercadológica, em especial, da publicidade. Incorporar valores imateriais nas matérias industriais, por um lado e, por outro lado, marcar os corpos 
consumidores com a marca das marcas. A publicidade produz enunciados, mas um enunciado só é completo dentro da enunciação e essa só se torna efetiva dentro das circunstâncias que a autorizam; tais circunstâncias são as do agenciamento. A subjetividade seria, para Deleuze e Guattari (1995, p. 16-17), um efeito de agenciamentos coletivos de enunciação. Modo de subjetivação que é também forma de sujeição: aos pressupostos implícitos do agenciamento, nesse caso, os pressupostos do mercado capitalista. Também, Pebart (2002) aponta, a partir de Deleuze e Guattari e de Foucault, a centralidade dos fenômenos da subjetividade no capitalismo cognitivo. Ele pergunta

De fato, como poderia o Império atual manter-se caso não capturasse o desejo de milhões de pessoas? Como conseguiria ele mobilizar tanta gente caso não plugasse o sonho das multidões à sua megamáquina planetária? Como se expandiria se não vendesse a todos a promessa de uma segurança, de uma felicidade, o desejo de um modo de vida? Afinal, o que nos é vendido o tempo todo, senão isto: maneiras de ver e de sentir, de pensar e de perceber, de morar e de vestir? O fato é que consumimos, mais do que bens, formas de vida - e mesmo quando nos referimos apenas aos estratos mais carentes da população, ainda assim essa tendência é crescente."

(Pebart, 2002)

Mas vender estilos de vida, eu diria, é uma estratégia do século passado. O problema parece mudar completamente para permanecer o mesmo, nessa segunda década do século XXI. Na era das redes sociais na Internet, o marketing quer forjar para si uma 
voz humana, entrar no diálogo um-para-um, tornar-se relevante, envolvente. Agora a disputa não é mais apenas pela atenção, mas pelo engajamento. Não basta seduzir, é preciso produzir porta-vozes. Se na década de 1960 se tratava de vender um estilo de vida, a questão agora é defender uma causa; as marcas querem ter militantes. Essa é uma ambição possível, uma vez que a informatização da vida cotidiana facilita a coleta de dados, além de ampliar o escopo das informações disponíveis para armazenamento, análise e classificação. Os equipamentos de uso corrente - do cartão de crédito ao telefone celular, da internet às TVs a cabo e digital - permitem a constante vigilância sobre os hábitos pessoais de compra, comportamento, informação e entretenimento. E, como demonstra Bruno (2013, p.146-157) viabilizam o desenvolvimento de databases cada vez mais sofisticados, dando margem ao cruzamento de informações, possibilitando traçar perfis demográficos e psicológicos cada vez mais completos, de modo a melhorar as estratégias de abordagem e, como não poderia deixar de ser, de vendas.

"Esqueça os anúncios" é o primeiro conselho de Iezzi (2010, p. 78), editora do setor Co.Create da revista FastCompany, ex-editora da editoria Creativity do jornal especializado em publicidade Advertising Age e palestrante especialista em criatividade no universo das marcas, aos futuros ou atuais redatores de publicidade que desejem enfrentar, e vencer, a árdua disputa pela atenção do público. Seu livro "The idea writers" (2010) caracteriza o atual redator publicitário de sucesso como um curador, contador de histórias, animador de conversas, e produtor de ideias. Isso porque, segundo a autora, no atual ambiente mediático, a comunicação de marketing não concorre com outros anúncios, mas com todo o conteúdo disponível para as pessoas consumirem em todas as mídias. O desafio seria tornar-se relevante, ou seja, criar "algo com que valha a pena as pessoas se engajarem, independentemente da marca. Só que, ao mesmo tempo, é preciso fazer o conteúdo ou experiência funcionar para a empresa ou marca 
envolvida". E a solução para tal problema seria, segundo PJ. Pereira, um dos criativos entrevistados por Iezzi, inverter o processo usual e "primeiro identificar a ideia de interesse para o consumidor, na qual a marca possa ter algum papel, e depois encontrar a melhor maneira de inserir aí o produto" (citado por Iezzi, 2010, p. 84).

Essa novidade do marketing aparece, de acordo com a resenha disponível no site Amazon, também no livro "Uprising: how to build a brand - and change the world - by sparking cultural movements", de Scott Goodson, fundador da Strawberryfrog, "a primeira agência de movimentos culturais do mundo". Trata-se, ainda segundo a resenha, das organizações aprenderem a "pegar a onda dos movimentos culturais para conectar-se genuinamente com as vidas e as paixões de pessoas em toda parte" (Amazon, 2014). Evidentemente precisamos considerar que a própria resenha é uma ferramenta de vendas, mas a promessa em si diz muito a respeito das aspirações em jogo.

No ano de 2013, uma campanha publicitária circulou on e offline, obtendo estrondoso sucesso de crítica, público e vendas ao trilhar justamente esse caminho.

\section{Eu sou mais bonita do que penso.}

Pelo menos é o que afirma a comunicação de uma conhecida marca de produtos de beleza e higiene pessoal. $\mathrm{O}$ audiovisual, largamente compartilhado pelos sites de redes sociais, em sua versão de três minutos, mostra, num primeiro instante, um salão amplo, claro graças às suas grandes janelas, com piso de tábua corrida e vazio, exceto por painéis duplos de desenhos, pendurados do teto. Impossível definir que lugar é aquele. A essa imagem fugaz, sucedem takes de um homem de meia idade; uma voz off, a dele provavelmente, se apresenta: "Sou um artista forense, trabalhei para o departamento de polícia de Santa Sé de 1995 a 2011". Uma legenda sobre a imagem informa seu nome e sua profissão: "Gil Zamorra. FBI trained forensic artist." Em seguida 
vemos o rosto de uma mulher loura que conta sua experiência para a câmera: “Cheguei a esse lugar onde nunca estivera e lá estava um cara..." Desaparece a mulher, e o vídeo mostra as imagens relativas à sua descrição. A voz de outra mulher, em off, completa: “... com uma prancheta de desenho..." Vemos o rosto dessa outra mulher, Melinda, segundo a legenda, que fala diante da câmera. “... não podíamos vê-lo, ele não podia nos ver...". Logo sua imagem é substituída pelas da situação que ela descreve. A fala da mulher é interrompida e a voz do homem solicita: "Fale-me sobre seu cabelo." O vídeo prossegue, alternando cenas do homem desenhando e tomadas do rosto das mulheres, uma por vez, falando para a câmera. No áudio, se alternam a voz do homem, que faz perguntas sobre a aparência delas, e a resposta das mulheres. Uma terceira mulher fala de seu queixo: “Ele meio que se projeta um pouco, especialmente quando sorrio..." A primeira mulher fala sobre seu maxilar: "Minha mãe dizia que eu tenho um maxilar grande." Uma quarta mulher fala sobre o formato de seu rosto: "Eu tenho um rosto meio gordo, mais para redondo." Uma quinta mulher fala sobre suas sardas: "Quanto mais velha fico, mais sardas ganho." Uma sexta mulher fala sobre sua testa: "Eu diria ter uma testa bastante grande".

Uma cena do desenhista forense explicando ao espectador que, depois das perguntas, com o desenho pronto, ele se despede das mulheres e elas partem, sem que se vejam, marca a passagem para a segunda parte do vídeo. Nessa, as mesmas pessoas são desenhadas novamente, a partir de descrições feitas por terceiros, desconhecidos. Finalmente, o vídeo mostra o momento em que as retratadas deparam seus retratos falados. Os desenhos feitos a partir de descrições dos terceiros representam as mulheres mais bonitas do que os desenhos feitos a partir de sua autodescrição. Elas reagem emocionadas e respondem a perguntas sobre a experiência ${ }^{3}$.

Com mais de 164 milhões de acessos via YouTube e vencedor do Grand Prix no Festival Internacional de Criatividade de Cannes 2013 o "documentário" (como diz a 
legenda no site da campanha) é tido como um sucesso. Divulgado inicialmente nos Estados Unidos, no Canadá, na Austrália e no Brasil, depois da grande repercussão alcançada em escassas 24h, recebeu versões em 25 línguas e divulgação em 45 canais da marca no YouTube (Barem, 2013). O partido tomado pela empresa anunciante se teria baseado em uma pesquisa global de mercado, segundo a qual apenas $4 \%$ das mulheres se afirmaram seguras quanto à sua aparência (Portugal, 2013). O briefing - documento em que a solicitação do serviço de criação é formalizada - pedia: "Only 4\% considere themselves beautiful. Help the other 96\% to feel more beautiful" (Penteado, 2013). Além da versão de três minutos do documentário, há uma estendida, de seis e meio minutos, e uma série de quatro depoimentos: um com o desenhista forense e outros com três das participantes (Dove, s/d).

O objetivo da campanha, idealizada no Brasil, por uma dupla de criação da sede paulista da agência global Ogilvy e filmada em São Francisco com mulheres de diferentes idades e tipos físicos, era recuperar a noção da "Real Beleza", utilizada pela marca desde 2004 e impulsionada por um comercial de 2007, com grande repercussão junto ao público. A ideia proposta, de realizar os retratos falados com um especialista forense, contava apenas com o dado estatístico para dar partida à experiência que originaria o audiovisual. Dentre as pessoas que aparecem no filme, o único plenamente informado da proposta era o desenhista. Em seu depoimento para um dos filmes da campanha, ele afirma ter-se entusiasmado com a perspectiva de realizar os retratos para o projeto, especialmente por ter uma filha. Os demais participantes não sabiam o que se passava, apenas que encontrariam algumas pessoas desconhecidas e responderiam a certas perguntas. Os publicitários autores enfatizam em entrevista o fato de terem trabalhado sem roteiro definido, sublinhando o caráter experimental e documentário do comercial. Também a escolha do diretor John X. Carey, cuja experiência é com documentários e não em publicidade, aponta para essa intenção (Meio\&mensagem, 2013; Portugal, 2013). 
Basta observar o volume de compartilhamentos, ou ler os comentários publicados no site da campanha, em sua maioria positivos e entusiasmados, para inferir que o comercial atingiu seu objetivo. Testemunham, ainda, a favor de sua eficácia como peça publicitária, o elevado número de visualizações que obteve, a quantidade de prêmios conquistados no setor, o volume de mídia espontânea mobilizada e, afinal, os resultados obtidos em termos de vendas dos produtos da marca. Porém, não pretendo discutir a qualidade do comercial, mas seu aspecto biopolítico.

$\mathrm{O}$ fato mesmo de ser uma campanha mobilizadora, emocionante, baseada em um problema atual e pungente torna mais penetrantes as palavras de ordem ativadas. As tomadas intimistas, o ar confessional das falas, a gentil autoridade do desenhista e a própria classificação como "documentário" de um "experimento" produzem um efeito de verdade extremamente persuasivo, pelo qual é fácil deixar-se envolver. Além disso, é difícil resistir à atmosfera de emoção que percorre o filme, enfatizada pela trilha sonora, que encontra seu ápice no momento da exibição, para as participantes, dos dois retratos-falados desenhados, lado a lado; momento em que se revela também, para elas, finalmente, todo o intuito da experiência, e para os espectadores a força inquestionável da emoção experimentada. O que o desenhista sugere à retratada, e a marca ao público em geral é: você é mais bonita do que você pensa. E quem não gosta de ouvir um elogio?

O comercial pretende questionar os modelos impostos de beleza, no entanto reafirma alguns pressupostos que, mesmo tendo sido apontados em artigos de jornal (Stampler, 2013) e em pelo menos um blog (jazzylittledrops), passam despercebidos para o grande público conquistado. Observe-se que o homem, o "especialista em desenho forense", representa a autoridade no assunto; a aparência é tida um critério fundamental de julgamento; e as mulheres são elas mesmas responsabilizadas por sua fraca auto- apreciação. Além disso, dentre sete retratadas, quatro são ocidentais 
brancas; todas têm idade até 40 anos; todas são magras; nenhuma foge aos padrões reconhecíveis de beleza.

Especialmente eloquente é o trecho em que uma mulher (Florence), ao deparar seus dois retratos no final do comercial, diz que ela deveria ser grata por sua beleza natural; reconhece a importância de ser bela em nossa sociedade, porque afeta a vida de uma pessoa, porque a favorece de diversas maneiras. Essa parece ser a antítese da mensagem intencionada, pois reafirma: sim, a beleza é fundamental, se você é bonita, seja grata. Mas e se você não é?

O encantamento com a história contada, como bem aponta Cunha (2013) para o filme Cinema Paradiso, aliado à identificação das espectadoras com aquelas mulheres belas e humanas, a tamanha emoção experimentada através delas afrouxam a crítica e abrem passagem para noções conflitantes com a própria causa defendida. Ao comover, a peça publicitária ativa um movimento e desativa momentaneamente o senso crítico. Aspectos questionáveis como o fato de os desenhos que representam a ideia de "menos bonita" enfatizarem traços de "feiura" como olheiras, um rosto redondo, uma testa grande, rugas que, no fim das contas, reforçam um modelo padronizado de beleza, como aponta Fridkis (citado por Stampler, 2013), são considerados desimportantes e relegados para segundo plano.

Para isso serve a criatividade em publicidade: é estratégica para captar e manter a atenção, seduzir, envolver e, mais recentemente, produzir engajamento. Significa provocar uma reação, incitar respostas, atiçar o desejo de participar e passar adiante aquela mensagem. Daí o recurso às causas: defender uma causa, supõe identificar-se intimamente com ela. Assumir para si e em si essa causa implica não só convicção, mas também ação: quer seja por meio de um clique de mouse diante do computador, quer seja diante da prateleira, ao escolher um produto da marca. Principalmente, a criatividade serve para nos levar a esquecer de que esse "documentário" é, antes 
de tudo, um texto persuasivo. A afirmação de um diretor da agência responsável pela campanha a respeito de seu sucesso, reportada na revista Exame, é elucidativa. Para ele, essa comunicação "sai do mundo da publicidade" e "transformou-se numa experiência social, com um conceito ao mesmo tempo simples e verdadeiro" (citado por Portugal, 2013).

A comunicação de marketing se revela mais do que uma tentativa de controle do discurso, por meio da regulação da visibilidade do que se diz (e ouve) a propósito da marca; ela se exerce como tentativa de controle dos corpos e da imaginação, dos comportamentos e dos sonhos, e promove a apropriação do tempo livre pelo trabalho voluntário, ainda que tal trabalho pareça entretenimento e se exerça por meio de um reles clique, para replicar a mensagem. O engajamento é a linha a costurar a própria malha do poder. Cada curtir, comentar, compartilhar acrescenta mais um aos muitos pontos de apoio em sua tessitura; somos nós, individualmente, os muitos nós que fecham a trama do tecido. Como diz Deleuze (1992, p. 224-225), um poder que se tornou maleável como uma serpente, e se move por cifras, controles de acesso, bancos de dados, amostragens, traços individuais.

Pelbart (2002) lembra-nos que sempre há resistência às diversas formas de assujeitamento em ação. Mencionamos as críticas expressas no blog e em artigos críticos publicados na mídia, que mostram que a captura não é completa. Outro espaço em certa medida fora do controle é o dos comentários. Em meu primeiro acesso ao site brasileiro da campanha, ainda em 2013, havia, ao todo, 78 comentários, e os dois primeiros, quando se organizam os resultados para iniciar por "best", protestavam veementemente contra os testes que a empresa proprietária da marca Dove, Unilever, faz em animais ao desenvolver seus produtos. Encontramos aqui um uso singular dessa tribuna: para colocar em discussão outro assunto, exatamente aquilo que o regente - a empresa - preferiria silenciar. A captura se reafirma, no entanto, quando as 
repostas a esses comentários, supostamente dadas por outros usuários, desqualificam agressivamente o protesto, em defesa da marca. Já em fevereiro de 2014, a página internacional da campanha exibe outros 142 comentários, todos elogiosos à campanha. Os primeiros não foram apagados, apenas rebaixados: podem ser lidos no fim da página, através de um link sob o título "also on real beauty sketches - retratos da real beleza Dove", apresentado por uma plataforma chamada Disqus, que reúne postagens e comentários de diversas origens num só site.

Qual é a mudança com relação à campanha do fusca? Não propriamente uma mudança, mas um aprofundamento. Da sedução ao engajamento. O público é agora convidado a se tornar agente, não só a aderir, mas a promover a ideia e junto com ela o produto - ou vice versa. A empresa não vende diretamente o produto, mas uma espécie de "utilidade pública": resolver um problema das mulheres com relação a sua autoestima. Como sabemos, a comunicação de marketing se apoia na novidade de seus conteúdos para emergir da enorme balbúrdia de informação e existir aos olhos do respeitável e disputado público, mas essa novidade nunca dura, pois está fadada a ser engolida pelo incessante fluxo da comunicação. Assim, não resta outra alternativa para as marcas senão realimentar constantemente o mesmo fluxo em que se dissolvem, pois é pela repetição e pela continuidade que suas mensagens forjam alguma durabilidade. Muito diferente do que acontece com as diferentes formas de invenção, cuja potência se inscreve no tempo da duração. Novamente é Deleuze (1992, p. 217) que aponta a distinção: "Criar sempre foi coisa distinta de comunicar." Porque, explica, comunicação é o que já temos em excesso, seria preciso "criar vacúolos de não-comunicação, interruptores, para escapar ao controle".

Na publicidade, ferramenta mais conhecida da comunicação de marketing, bem como em muitas outras produções da indústria criativa, impera a visão da criatividade proveniente da psicologia, mencionada no início deste artigo: um recurso humano 
inesgotável que oferece respostas inovadoras a um problema dado. Nessas respostas, no entanto, os princípios da sociedade não são colocados em questão, não há ruptura com relação ao modelo, não ocorre, portanto, genuína invenção. No caso da campanha da Dove isso é visível não só na concepção do problema, mas também na individualização da solução. Cada mulher deve resolver a questão da aparência, do modo como solicita a produção industrial de subjetividade: "se trabalhando" para fortalecer a autoestima e reconhecer-se bela. E usando os produtos da marca, naturalmente.

\section{REFERÊNCIAS}

AMAZON: Uprising: How to build... Disponível em: <http://www.amazon.com/Uprising-Brand---WorldSparkingMovements/dp/0071782826/ref=sr_1_1?ie=UTF8\&qid=1324484917\&sr=8-1>. Acesso em: 27 fev. 2014.

BAREM, Manu. 6 segredos do "Dove Retratos da Real Beleza" revelados pela agência que criou o viral. Youpix, setembro de 2013. Disponível em: <http://www.youpix.com.br/news/segredos-do-dove-retratos-dareal-beleza/. Acesso em: 14 mar. 2014.

BRUNO, Fernanda. Máquinas de ver, modos de ser: vigilância, tecnologia e subjetividade. Capítulo III. Porto Alegre: Sulina, 2013.

BURROWES, Patricia. Prontoparaoconsumo. In: CAIAFA, J.; EL HAJJI, M. Comunicação e sociabilidade: cenários contemporâneos. Rio de Janeiro, Mauad X, 2007.

CARRASCOZA, João A. A evolução do texto publicitário: associação de palavras como elemento de sedução na publicidade. São Paulo: Futura, 1999.

CUNHA, Paulo Roberto Ferreira da. Cinema Paradiso - Um filme, muitos discursos, diferentes Itálias. In: COMUNICOM 2013 - Congresso Internacional em Comunicação e Consumo, São Paulo. Anais do Comunicom 2013. São Paulo: ESPM, 2013.

DELEUZE, Gilles. Conversações, 1972-1990. Rio de Janeiro: Ed. 34, 1992.

GUATTARI, Félix. Mil Platôs - capitalismo e esquizofrenia. Rio de Janeiro: Ed. 34, 1995. Vol. 2.

DDB: Bill Bernbach Said. Disponível em: <http://www.ddb.com/BillBernbachSaid/about-the-book.html\#> . Acesso em: 4 jun. 2014.

DOVE. Real Beauty Scketches. Disponível em: <http://retratosdarealbeleza.dove.com.br>. Acesso em: 24 mar. 2014. 
EVANS, Sophie Jane; POW, Helen. Former Malboro man, 72, becomes fifth actor from iconic cigarette ads to die of lung disease. Mail online. 27 january 2014. Disponível em: <http://www.dailymail.co.uk/news/ article-2546554/Ex-Marlboro-Man-dies-smoking-related-respiratory-failure.html>. Acesso em: 14 fev. 2014.

FIGUEIREDO, C. Redação publicitária: sedução pela palavra. São Paulo: Pioneira Thomson Learning, 2005.

FOUCAULT, Michel. Nascimento da Biopolítica: curso dado no Collège de France (1978-1979). São Paulo: Martins Fontes, 2008.

GREMAUD et al. Manual de Economia. São Paulo: Saraiva, 2003.

HALLOCK, M. The creative revolution. In: History of advertising (with a little design). Disponível em: $<$ http://historyofads.the-voice.com/the-creative-revolution>. Acesso em: jan. 2014.

HOBSBAWN, Eric. A era dos extremos: o breve século XX: 1914-1991. São Paulo: Companhia das Letras, 1995. IEZZI, Teressa. The Idea writers: copywriting in a new media and marketing era. New York: Palgrave Macmillan, 2010.

JAZZYLITTLEDROPS. Disponível em: <http://jazzylittledrops.tumblr.com/post/48118645174/why-dovesreal-beauty-sketches-video-makes-me>. Acesso em: 10 jan. 2014.

KASTRUP, Virginia. A invenção de si e do mundo. Uma introdução do tempo e do coletivo no estudo da cognição. Belo Horizonte: Autêntica, 2007 [1999].

MARKETINGBEST: Case - Unilever: Campanha Dove Retratos da Real Beleza. Publicado: quinta-feira, 14 de novembro de 2013. Disponível em: <http://www.marketingbest.com.br/marketing-best/case-unilevercampanha-dove-retratos-da-real-beleza/>. Acesso em: 13 mar. 2014.

MEIO\&MENSAGEM: Por dentro de “Retratos da Real Beleza" 20 de junho de 2013. Disponível em: <http:// cannes.meioemensagem.com.br/cobertura/2013/cannes/festival/festival/Por-dentro-de-Retratos-da-RealBeleza.html>. Acesso em: 14 mar. 2014.

NOVAC, Jenny. Malboro Man. CigaretteZoom.com - Zoom on Cigarettes. July 25, 2011. Disponível em: <http:// cigarettezoom.com/marlboro-man/>. Acesso em: 10 jan. 2014.

OGILVY, David. Confissões de um publicitário. Rio de Janeiro: Bertrand Brasil, 2003 [1963].

O PORTAL da história. Marcas e produtos. Disponível em: <http://www.arqnet.pt/portal/empresas/vw_ campanha.html>. Acesso em: 22 jan. 2014.

PELBART, Peter Pal: Biopolítica e biopotência no coração do Império. Multitudes 9, mai-juin 2002. Disponível em: <http://www.multitudes.net/Biopolitica-e-Biopotencia-no/ >. Acesso em: 20 mar. 2014.

PENTEADO, Cláudia. Real Beauty Sketches: a história de um Grand Prix. Época Negócios, 17 set. 2013. Disponível em: <http://colunas.revistaepocanegocios.globo.com/mundocriativo/2013/09/17/real-beautysketches-a-historia-de-um-grand-prix>. Acesso em: 24 mar. 2014. 
POPE, Daniel. Making Sense of Advertisements. In: History Matters: The U.S. Survey Course on the Web, June 2003. Disponível em: <http://historymatters.gmu.edu/mse/ads/>. Acesso em: 20 jan. 2014.

PORTUGAL, Mirela. Como nasceu o viral Dove Real Beleza, feito por brasileiros. Exame.com, 25 jun. 2013. Disponível em: <http://exame.abril.com.br/marketing/noticias/como-nasceu-o-viral-dove-real-beleza-feitopor-brasileiros?page=1>. Acesso em: 14 mar. 2014.

STAMPLER, Laura: Why people hate Dove's 'Real Beauty Sketches' Video. Business Insider, 22 abr. 2013. Disponível em: <http://www.businessinsider.com/why-people-hate-doves-real-beauty-ad-2013-4>. Acesso em: 25 de mar. 2014.

\section{NOTAS}

1 “Ter uma afirmação de vendas é uma coisa, vendê-la é outra, completamente diferente."

2 "A criatividade corretamente praticada deve resultar em mais vendas, alcançadas de forma mais econômica. A criatividade corretamente praticada pode tirar suas afirmações do pântano da mesmice e torná-las aceitas, acreditadas, persuasivas, urgentes."

3 Vídeos disponíveis em: <http://retratosdarealbeleza.dove.com.br/>. Acesso em: 13 mar. 2014.

Recebido em: 04 jun. 2014

Aceito em: 24 ago. 2014

\section{Endereço da autora:}

Patricia Cecilia Burrowes < patricia.burrowes@eco.ufri.br>

Escola de Comunicação da Universidade Federal do Rio de Janeiro ECO - UFRJ

Av. Pasteur, 250 - Palácio Universitário

22290-240 Praia Vermelha, RJ, Brasil 